\title{
Analysis of Food Quality and Price in Increasing Customer Satisfaction at Anantara Uluwatu Bali Resort
}

\author{
I Ketut Akas Wicaksana ${ }^{1}$, Elvira Septevany ${ }^{2}$, I Nyoman Winia ${ }^{3}$, Ni Nym Gst \\ Suci Murni ${ }^{4}$
}

\author{
Affiliation \\ ${ }^{1}$ Tourism Department, Politeknik Negeri Bali, Indonesia \\ ${ }^{2}$ Tourism Department, Politeknik Negeri Bali, Indonesia \\ ${ }^{3}$ Tourism Department, Politeknik Negeri Bali, Indonesia \\ ${ }^{4}$ Tourism Department, Politeknik Negeri Bali, Indonesia
}

\section{Correspondence}

Elvira Septevany. Tourism Department, Politeknik Negeri Bali, Indonesia, Jl. Raya Uluwatu No.45, Jimbaran, Kuta Selatan, Kabupaten Badung, Bali. Email: elvira_s@pnb.ac.id

\begin{abstract}
The purpose of this research was to analyze the effect of food quality, and price in increasing customer satisfaction at Anantara Uluwatu Bali Resort. This research was conducted at Anantara Uluwatu Bali Resort at Botol Biru Bar \& Grill using 30 visitors as research samples. The data collection method used a questionnaire and observation, where the data collected was then analyzed using Multiple Linear Regression Analysis. The results showed that the variables of food quality, and price had a positive and significant effect on customer satisfaction at Anantara Uluwatu Bali Resort. Anantara Uluwatu Bali Resort is expected to be able to maintain food quality and prices and be able to improve food quality ranging from variety, appearance, food health, taste, and temperature to food, and to increase prices according to food quality during the pandemic.
\end{abstract}

Keywords: Food Quality; Price; Customer Satisfaction

Article Information:

Submitted 4 july 2021 |Revised 22 July 2021 |Accepted 28 July 2021 
to the original publication and author(s). The full terms of this license may be seen at http://creativecommons.org/licenses/by/4.0/legalcod

\section{Introduction}

Anantara Uluwatu Bali Resort is a 5-star resort hotel in Uluwatu area located on Jl. PemutihLabuan Sait, Uluwatu, Bali, Indonesia. Anantara Uluwatu Bali has 75 rooms and 3 restaurants. One of the restaurants owned by Anantara Uluwatu Bali Resort to meet the needs and satisfaction of customers, namely Botol Biru Bar \&Grill which is a restaurant devoted to lunch and dinner at Anantara Uluwatu Bali Resort. The types of dishes or meals offered at Botol Biru Bar \& Grill are Western food and Grill that serves more baked goods. In addition, Botol Biru Bar $\&$ Grill also offers a weekly Barbeque Buffet on Saturdays featuring the process of grilling seafood or meat selected by customers directly in the restaurant area to attract tourists to visit and enjoy food at Botol Biru Bar \& Grill. The number of tourists visiting Botol Biru Bar \& Grill at Anantara Uluwatu Bali Resort in 2016 - 2020 can be seen in Figure 1.

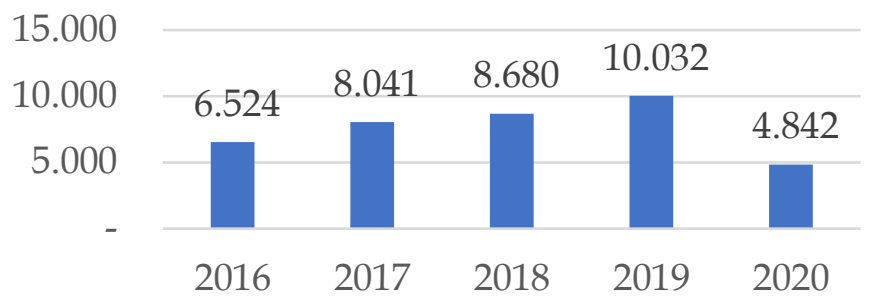

Figure 1. Number of Tourist Visits to Botol Biru Bar \& Grill at Anantara Uluwatu Resort Bali in 2016 - 2020 Source: F\&B Departement Anantara Uluwatu Bali Resort 2020

The Figure 1 above shows that in 2020 the number of tourist visits decrease drastically from 10,032 in 2019 to 4,842 in 2020 due to the covid 19 pandemic. The decrease in the number of visits makes the hotel must be creative so that the hotel can survive. Providing quality food and affordable prices is one way for hotels to survive during the pandemic. Quality food is one of the products owned by the hotel that can meet customer needs. There are several reasons that explain why quality food is one of the products owned by hotels that can meet customer needs, namely because product quality is one of the main goals in the hospitality industry that can increase product competitiveness in providing satisfaction to customers. Satisfaction depends on the quality of the company's products because higher level of product quality produces higher level of customer satisfaction. The role of product quality greatly determines the desires of these consumers so that with product quality, customer satisfaction will be achieved (Diputra \& Yasa, 2021). Another reason put forward by previous research also states that the various kinds of food offered by hotels really need to maintain food quality and continue to innovate so that they can satisfy customers (Sugianto \& Sugiharto, 2013). Superior food quality is a key marketing tool that can be used to satisfy and retain customers and can ensure a positive buying experience (Hanaysha, 2016). Existing literature provides empirical support that food quality has a significant influence on customer satisfaction (Hidayat et al., 2020). Because food quality is the main determinant of customer satisfaction and re-subscribe intention (Abdullah et al., 2018). Customer satisfaction is influenced by the quality of food that has food serving procedures that are in accordance with customer expectations (Mayliza, 2019). In particular, the quality of food in this case the temperature of the food, the cleanliness and appearance of the food, and the 


\section{Ketut Akas Wicaksana}

health of the food greatly affect customer satisfaction (Kannan, 2017). Furthermore, healthy food made from fresh ingredients affects customer satisfaction for long-term relationships and menu variations that directly affect customer satisfaction to come back (Nor Azureen et al., 2016). Therefore, a restaurant in a hotel must have quality food and in accordance with customer tastes or expectations so that it can make customers feel satisfied. This is supported by previous researchers who stated that the relationship between food quality and customer satisfaction is an important component in explaining customer intention to return and market intention by word of mouth (Konuk, 2019).

In addition to the quality of the food, the price must also be considered to increase customer satisfaction. This statement is supported by several previous studies which state that price has a significant and positive effect on customer satisfaction (Wantara \& Tambrin, 2019; Montolalu, 2013). Because, price plays an important role in communicating the quality of a product (Sugianto \& Sugiharto, 2013). Previous research has also stated that price is the main focus of customers (Sudari et al., 2019). Customers will feel very satisfied if the price of the food purchased is in accordance with the quality. This statement is supported by previous research which states that the quality of a product and the right price can increase customer satisfaction (Razak et al., 2016). Because, customer satisfaction can be realized by maintaining the appropriateness of the price perceived by the customer (Setiawan et al., 2020). Where these two things from food quality and price will satisfy customers and can benefit the company to win the competition. Because, if customers are satisfied, they will repurchase and recommend to relatives, friends, and others to buy at the same place (Susepti et al., 2017). Because, customer satisfaction is an important marketing priority (Ghulam et al., 2017).

Based on the explanation described above, this research analyzes the quality of food and price in increasing customer satisfaction at Anantara Uluwatu Bali Resort.

\section{Research Method}

The research was conducted at Anantara Uluwatu Resort Bali at Botol Biru Bar \& Grill. The object of this research is to analyze the quality of hotels based on food quality and price in improving customer satisfaction at Anantara Uluwatu Resort Bali. The types of data used in this study are quantitative and qualitative data (Sugiyono, 2013). The quantitative data in the form of data on food quality, price, and customer satisfaction in the form of a Likert scale of 1 to 5 . Meanwhile the results of the questionnaire regarding food quality, price, and customer satisfaction were then explained in a qualitative descriptive. There are two technique to collected the data are observation and distribute the questionnaires (Sugiyono, 2013). In this research, researchers used non-participant observations to observe how the process of serving food and how things were during the pandemic at Botol Biru Bar \& Grill at Anantara Uluwatu Bali Resort. Data collection by non-participant observation will not get in-depth data, and does not reach the level of meaning. Meanings are the values behind visible, spoken, and written behavior (Sugiyono, 2013:146). The second technique of collected the data was distributing questionnaires to customers who enjoy food at Botol Biru Bar \& Grill at Anantara Uluwatu Resort Bali. This 
questionnaire data is given in the form of a barcode and placed on each customer's table so as not to disturb customers who want to enjoy food at this restaurant.

The population in this research are customers who visit and enjoy food at Botol Biru Bar \& Grill at Anantara Uluwatu Resort Bali. Sampling technique is Incidental Sampling and to determine the number of samples is 10 times the number of variables that is $10 \times 3=30$ that already represent a decent sample size in the study (Sugiyono, 2013). The data collection method in this research was conducted in several stages, namely observation and questionnaire.

Instrument Test uses validity and reliability test on the questionnaire used. Validity test is conducted by comparing $r$-calculated value with $r$-table, where the data in the questionnaire is said to be valid if $r$-count $>r$-table, to determine the $r$-table value with a free degree $n-k$, where $\mathrm{n}$ is the number of respondents that is 30 , and $\mathrm{k}$ is the sum of the research variables that is 3 . The $r$-table value with a free degree $n-k=30-3=27$ is 0.367 , so the details of the statement on the questionnaire are declared valid if the $r$-count is greater than 0.367 . Reliability indicates the consistency of a measuring device in measuring the same symptoms, where it is said to be reliable if the alpha value is greater than 0.60 means the data is reliable and worthy of use as a measuring instrument (Sinambela, 2019). The analysis techniques used in this study are multiple linear regression analysis which includes classical assumption test, multiple linear regression, hypothesis test, and determination coefficient test (Sinambela, 2019).

\section{Results and Discussion}

Validity Test

Testing the validity of each question item on the questionnaire used item analysis which correlated the score of each item with the total score. Valid shows the degree of accuracy between data that occurs on the object and data that can be collected by researchers. That is, each statement on the food quality, price, and customer satisfaction questionnaire can reveal with certainty the effect of food quality and price on customer satisfaction. The validity test was carried out using Pearson's Correlation with the help of the SPSS for Windows version 25.

Table 1. Table of Validity Test

\begin{tabular}{|c|c|c|c|}
\hline Variable & Item & r-count & Validity \\
\hline & Food variations have met the needs during the pandemic. & 0.737 & Valid \\
\hline & $\begin{array}{l}\text { The food display is interesting and has appropriate portions } \\
\text { and already meets the standards of dishes in the pandemic. }\end{array}$ & 0.684 & Valid \\
\hline \multirow[t]{5}{*}{ Food Quality } & The taste of the food is delicious. & 0.757 & Valid \\
\hline & $\begin{array}{l}\text { Food health is very good and already meets the standards } \\
\text { of dishes in the pandemic. }\end{array}$ & 0.818 & Valid \\
\hline & Food temperature according to the dish. & 0.638 & Valid \\
\hline & Food prices are reasonable and acceptable. & 0.616 & Valid \\
\hline & The price of food is comparable to the portion of food. & 0.723 & Valid \\
\hline \multirow[t]{2}{*}{ Price } & The price of the food is according to the taste of the food. & 0.751 & Valid \\
\hline & $\begin{array}{l}\text { Overall, the pricing options are superior to other service } \\
\text { providers. }\end{array}$ & 0.772 & Valid \\
\hline $\begin{array}{l}\text { Customer } \\
\text { Satisfaction }\end{array}$ & $\begin{array}{l}\text { Customers have been getting food at prices that are in line } \\
\text { with expectations. }\end{array}$ & 0.563 & Valid \\
\hline
\end{tabular}




\section{Ketut Akas Wicaksana}

\begin{tabular}{llcc}
$\begin{array}{l}\text { Food quality and has been in line with customer } \\
\text { expectations. }\end{array}$ & 0.493 & Valid \\
$\begin{array}{l}\text { Customers are satisfied with the presentation of food that } \\
\text { has met the standards of dishes during the pandemic. } \\
\text { Customers will be willing to recommend Anantara Uluwatu } \\
\text { Bali Resort as accommodation and dining to family, friends, } \\
\text { or others. }\end{array}$ & 0.697 & Valid \\
$\begin{array}{l}\text { Customers will feel loyal and interested in repurchasing food } \\
\text { products provided at Anantara Uluwatu Bali Resort. }\end{array}$ & 0.637 & Valid \\
\hline
\end{tabular}

Source: data processed by researchers, 2021

Based on the output in Table 1, the total item correlation value for the 14 questionnaire items > $r$ table, so that all items can be said to be valid to be used in this research.

Reliability Test

The reliability test of the instrument in this study was assessed through the magnitude of the Cronbach's Alpha coefficient, which shows the internal consistency of the items that underlie a variable. Calculation of the Cronbach's Alpha coefficient using the SPSS for Windows version 25.

Table 2. Table of Reliability Test

\begin{tabular}{lcc}
\hline \multicolumn{1}{c}{ Variable } & Cronbach's Alpha & Reliability \\
\hline Food Quality & 0.775 & Reliable \\
Price & 0.685 & Reliable \\
Customer Satisfaction & 0.629 & Reliable \\
\hline
\end{tabular}

Source: data processed by researchers, 2021

The results of the analysis in Table 2 , it can be seen that the value of food quality is 0.775 , the price is 0.685 , and customer satisfaction is 0.629. Based on Cronbach's Alpha value above 0.60, it can be concluded that the questionnaire on the variables of food quality, price, and customer satisfaction is declared reliable so that it can be used in this research.

Normality Test

The Normality test aims to test whether in the regression model, variables are normally distributed. The normality test in this study was conducted with unstandardized residual values from the regression model using the One Sample Kolmogorov-Smirnov Test.

Based on the test results in Table 3, the test results of one sample Kolmogorov-Smirnov Test produced asymptotic significance of $0.200>0.05$. Based on these results, it can be concluded that residual spread normally.

Table 3. Normality Test Results

\begin{tabular}{llr}
\hline \multicolumn{3}{c}{ One-Sample Kolmogorov-Smirnov Test } \\
\cline { 3 - 3 } & & Unstandardized Residual \\
\hline $\mathrm{N}$ & & 30 \\
Normal Parameters & Mean & 0.0000000 \\
& Std. Deviation & 0.98020589
\end{tabular}




\section{Ketut Akas Wicaksana}

\begin{tabular}{llr} 
Most Extreme & Absolute & 0.101 \\
Differences & Positive & 0.088 \\
& Negative & -0.101 \\
& & 0.101 \\
Test Statistic & & .200 \\
\hline
\end{tabular}

Multicollinearity Test

The multicollinearity test in this study was conducted to see if there was or not a correlation between free variables $(X)$ on the regression model. If there is a strong correlation, then it can be said that there has been a problem of multicollinearity.

Table 4. Multicollinearity Test Results

\begin{tabular}{|c|c|c|c|c|c|}
\hline \multirow{2}{*}{\multicolumn{2}{|c|}{ Model }} & \multirow{2}{*}{$\mathrm{t}$} & \multirow{2}{*}{ Sig. } & \multicolumn{2}{|c|}{ Collinearity Statistics } \\
\hline & & & & Tolerance & VIF \\
\hline \multirow{3}{*}{1} & (Constant) & 2.200 & 0.037 & & \\
\hline & Food Quality & 3.873 & 0.001 & 0.672 & 1.489 \\
\hline & Price & 3.784 & 0.001 & 0.672 & 1.489 \\
\hline
\end{tabular}

Source: data processed by researchers, 2021

Based on the results of Variance Inflation Factor (VIF) value in Table 4 shows the value of VIF < 10 , it can be concluded that the absence of multicollinearity between free variable (food quality and price).

Heteroskedasticities Test

The heteroskedasticity test in this study aims to test whether in the regression model variance error occurs from residual one observation to another.

Table 5. Heteroskedasticities Test Results

\begin{tabular}{|c|c|c|c|c|c|c|}
\hline & \multirow[t]{2}{*}{ Model } & \multicolumn{2}{|c|}{$\begin{array}{c}\text { Unstandardized } \\
\text { Coefficients }\end{array}$} & \multirow{2}{*}{$\begin{array}{c}\begin{array}{c}\text { Standardized } \\
\text { Coefficients }\end{array} \\
\text { Beta } \\
\end{array}$} & \multirow[t]{2}{*}{$\mathrm{t}$} & \multirow[t]{2}{*}{ Sig. } \\
\hline & & B & Std. Error & & & \\
\hline \multirow[t]{3}{*}{1} & (Constant) & 3.890 & 1.138 & & 3.419 & 0.002 \\
\hline & Food Quality & -0.072 & 0.057 & -0.263 & -1.271 & 0.215 \\
\hline & Price & -0.104 & 0.079 & -0.272 & -1.315 & 0.200 \\
\hline
\end{tabular}

Source: data processed by researchers, 2021

Based on Glejser test results in Table 5, obtained variable significance value of food quality of 0.215 greater than 0.05 , as well as price significance value of 0.200 greater than 0.05 . Based on this explanation, it can be concluded that there is no heteroskedasticities problem in the regression model.

Multiple Linear Regression Analysis 


\section{Ketut Akas Wicaksana}

Multiple linear regression analyses are used to answer the hypothesis of whether food quality and price partially or simultaneously affect improving customer satisfaction.

Table 6. Recapitulation of Multiple Linear Regression Analysis Results

\begin{tabular}{|c|c|c|c|c|c|}
\hline \multirow{2}{*}{ Model } & \multicolumn{2}{|c|}{$\begin{array}{l}\text { Unstandardized } \\
\text { Coefficients }\end{array}$} & \multirow{2}{*}{$\begin{array}{c}\text { Standardized } \\
\text { Coefficients } \\
\text { Beta } \\
\end{array}$} & \multirow[t]{2}{*}{$\mathrm{t}$} & \multirow{2}{*}{ Sig. } \\
\hline & B & Std. Error & & & \\
\hline (Constant) & 4.476 & 2.034 & & 2.200 & 0.037 \\
\hline Food Quality & 0.394 & 0.102 & 0.483 & 3.873 & 0.001 \\
\hline Price & 0.533 & 0.141 & 0.472 & 3.784 & 0.001 \\
\hline$R$ & & 0.847 & & & \\
\hline R Square $\left(R^{2}\right)$ & & 0.718 & & & \\
\hline Adjusted R Square & & $: 0.697$ & & & \\
\hline F-count & & $: 34.321$ & & & \\
\hline F-count probability & & $: 0.000$ & & & \\
\hline
\end{tabular}

Source: data processed by researchers, 2021

Based on Table 6, constant coefficient ( $a$ ) has value of 4.476, food quality coefficient ( $b 1$ ) has value of 0.394 , price coefficient $(b 2)$ has value of 0.533 was obtained. Thus, the value of the regression equation can be formulated as follows:

$Y=a+b 1 X 1+b 2 X 2$

$Y=4.476+0.394 X 1+0.533 X 2$

The effect of food quality in increasing customer satisfaction at Anantara Uluwatu Bali Resort The results of the recapitulation of multiple regression analysis in Table 6 showed that food quality had a positive and significant effect in improving customer satisfaction at Anantara Uluwatu Bali Resort, this is known in the t-test calculation where $t$-count of 3.873 is greater than t-tables of 2.052. This is because the food served at Anantara Uluwatu Bali Resort has a variety of foods that meet in the pandemic, attractive food display, food health meets the standards of the dishes in the pandemic, the taste of good food, as well as the temperature of the dishes served according to the type of dish.

The results of this research support research from Hanaysha (2016) which states that food quality has direct and positive influence on customer satisfaction. This research is also in line with the research presented by Evirasanti (2016), which states that the quality of food has positive and significant effect on customer satisfaction. The quality of the food is reviewed in terms of taste, appearance, menu variations, as well as temperature. The taste of delicious food, the appearance of food that adds to the appetite, the varied restaurant menu, and the presentation of dishes at the right temperature cause customers to be satisfied.

The effect of price in increasing customer satisfaction at Anantara Uluwatu Bali Resort Partial hypothetical test results show that prices have positive and significant effect in improving customer satisfaction at Anantara Uluwatu Bali Resort. This is known in the calculation of t test, where t-counted of 3.784 is greater than t-table of 2.052. This is because the price of food at 


\section{Ketut Akas Wicaksana}

Anantara Uluwatu Bali Resort has price that corresponds to the food served at Anantara Uluwatu Bali Resort, ranging from the portion and taste of appropriate food in the pandemic that can meet the satisfaction of customers who make food purchases at Anantara Uluwatu Bali Resort. The results of this research are also in line with the research put forward by Salsabilah \& Sunarti (2018), which states that price significantly affects customer satisfaction. Price affects customer satisfaction, if the price is more affordable and in accordance with customer expectations, then customer satisfaction will increase. This research also supports research from Konuk (2019) which states that price significantly affects customer satisfaction. Prices that match the quality of the food served that are considered worthy to be purchased by customers can increase high satisfaction and ultimately increase return visits and word of mouth intentions.

\section{Conclusion}

Based on the results of multiple linear regression analysis, the following conclusions can be drawn:

a. The value of constant coefficient $(a)$ of 4.476 is a constant or a state when the customer satisfaction variable has not been influenced by other variables, namely the food quality variable $(X 1)$ and price $(X 2)$.

b. The value of regression coefficient $X 1(b 1)$ is 0.394 , indicating that the food quality variable has a positive influence on customer satisfaction, which means that every 1 unit increase in the food quality variable will affect customer satisfaction by 0.394 , assuming that other variables are not examined in this study.

c. The value of regression coefficient $\mathrm{X} 2(b 2)$ is 0.533 , indicating that the price variable has a positive influence on customer satisfaction, which means that every 1 unit price increase will affect customer satisfaction by 0.533 , assuming that other variables are not examined in this study.

\section{References}

Abdullah, D., Hamir, N., Nor, N. M., Jayaraman, K., \& Rostum, A. M. M. (2018). Food quality, service quality, price fairness and restaurant re-patronage intention: The mediating role of customer satisfaction. International Journal of Academic Research in Business and Social Sciences, 8(17), 211-226. https://doi.org/10.6007/IJARBSS/v8-i17/5226

Diputra, A. W., \& Yasa, N. N. (2021). the Influence of Product Quality, Brand Image, Brand Trust on Customer Satisfaction and Loyalty. American International Journal of Business Management (AIJBM), 4(1), 25-34. http://118.97.187.12/pustaka/files/17726/jurnal/theimpact-of-service-quality-product-quality-and-price-on-customer-satisfaction.pdf

Evirasanti, M. (2016). Pengaruh Kualitas Makanan, Kualitas Layanan dan Lingkungan Fisik Terhadap Kepuasan dan Behavioral Intention ( Study di Metis Restaurant ). E-Jurnal Ekonomi Dan Bisnis Universitas Udayana, 12(5), 4331-4358. https://ojs.unud.ac.id/index.php/EEB/article/view/24395/16242

Ghulam, M., Abubakar, C., Bilal, A., Munim, B., \& Junaid, I. (2017). Effect of Food Quality on Customer Perceived Satisfaction Level and Mediating Effect of Food Safety on Them. International Journal of New Technology and Research, 3(1), 34-41. https://www.academia.edu/36073353/Effect_of_Food_Quality_on_Customer_Perceived_ 


\section{Ketut Akas Wicaksana}

Satisfaction_Level_and_Mediating_Effect_of_Food_Safety_on_Them

Hanaysha, J. (2016). Testing the effects of food quality, price fairness, and physical environment on customer satisfaction in fast food restaurant industry. Journal of Asian Business Strategy, 6(2), 31-40. https://doi.org/10.18488/journal.1006/2016.6.2/1006.2.31.40

Hidayat, D., Bismo, A., \& Basri, A. R. (2020). the Effect of Food Quality and Service Quality Towards Customer Satisfaction and Repurchase Intention (Case Study of Hot Plate Restaurants). Manajemen Bisnis, 10(1), 1. https://doi.org/10.22219/jmb.v10i1.11913

Kannan, R. (2017). The Impact of Food Quality On Customer Satisfaction And Behavioural Intentions: A Study On Madurai Restaurant. Innovative Journal of Business and Management, 6(03), 34-37. https://doi.org/10.15520/ijbm.vol6.iss3.67.pp34-37

Konuk, F. A. (2019). The influence of perceived food quality, price fairness, perceived value and satisfaction on customers' revisit and word-of-mouth intentions towards organic food restaurants. Journal of Retailing and Consumer Services, 50(February), 103-110. https://doi.org/10.1016/j.jretconser.2019.05.005

Mayliza, R. (2019). Analisis Customer Satisfaction Dan Behavioral Intention Dilihat Dari Service Quality, Food Quality Dan Price/Value Di Restoran Mcdonald'S Depok. https://doi.org/10.31219/osf.io/e2jrt

Montolalu, M. (2013). the Impact of Service Quality and Price To Customer Satisfaction and. Jurnal EMBA, 1(4), 1491-1498.

Nor Azureen, R., Shahril, H., Ashraf Siddik Khan, A. R. S., Putri Dahlia, A. R., \& Noor Saliza, S. (2016). The Influence of Food Quality on Customer Satisfaction in Fine Dining Restaurant: Case in Penang. International Academic Research Journal of Business and Technology, 2(2), 45-50. http://www.iarjournal.com/wp-content/uploads/IARJBT2016_2_45-50.pdf

Razak, I., Nirwanto, N., \& Triatmanto, B. (2016). The impact of product quality and price on customer. In Journal of Marketing and Consumer Research (Vol. 30, pp. 59-68).

Salsabilah, T., \& Sunarti. (2018). Pengaruh Food Quality, Dining Atmosphere Dan Kesesuaian Harga Terhadap Kepuasan Pelanggan Cafe Ria Djenaka Shining Batu. Jurnal Administrasi Bisnis (JAB), 54(1), 140-148. http://administrasibisnis.studentjournal.ub.ac.id/index.php/jab/article/view/2226

Setiawan, E. B., Wati, S., Wardana, A., \& Ikhsan, R. B. (2020). Building trust through customer satisfaction in the airline industry in Indonesia: Service quality and price fairness contribution. Management Science Letters, 10(5), 1095-1102. https://doi.org/10.5267/j.msl.2019.10.033

Sinambela, L. P., \& Chotim, E. E. (2019). Statistika Sosial: Teori Dan Aplikasi Untuk Mahasiswa Dan Peneliti IImu-IImu Sosial Edisi 1. Depok: PT RajaGrafindo Persada.

Sudari, S. A., Tarofder, A. K., Khatibi, A., \& Tham, J. (2019). Measuring the critical effect of marketing mix on customer loyalty through customer satisfaction in food and beverage products. Management Science Letters, 9(9), 1385-1396. https://doi.org/10.5267/j.msl.2019.5.012

Sugianto, J., \& Sugiharto, S. (2013). Analisa Pengaruh Service Quality, Food Quality dan Price Terhadap Kepuasan Pelanggan Restoran Yung Ho Surabaya. Jurnal Manajemen Pemasaran Petra, Vol.1(2), 1-10.

Sugiyono. (2013). Metode Penelitian Kuantitatif, Kualitatif, dan R\&D. In Alfabeta, Bandung (19th ed., p. 346). ALFABETA, CV. 


\section{Ketut Akas Wicaksana}

Susepti, A., Hamid, D., \& Kusumawati, A. (2017). PENGARUH KUALITAS PELAYANAN TERHADAP KEPUASAN DAN LOYALITAS TAMU HOTEL (Studi tentang Persepsi Tamu Hotel Mahkota Plengkung Kabupaten Banyuwangi). Jurnal Administrasi Bisnis S1 Universitas Brawijaya, 50(5), 27-36.

Wantara, P., \& Tambrin, M. (2019). ITHJ International Tourism and Hospitality Journal The Effect of Price and Product Quality Towards Customer Satisfaction and Customer Loyalty on Madura Batik. International Tourism and Hospitality Journal, 2(1), 1-9. https://rpajournals.com/ithj:https://rpajournals.com/ithj 